\title{
The first commandment in the Heidelberg Catechism: Theological insights of Philipp Melanchthon and Zacharias Ursinus
}

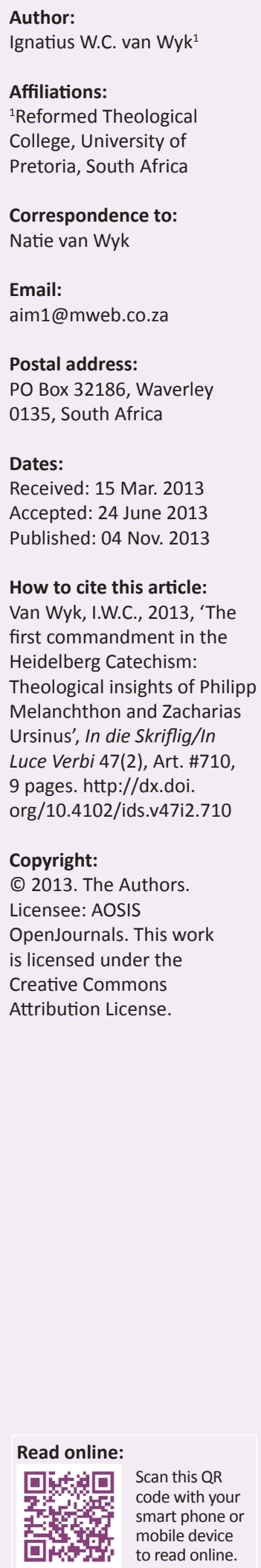

This article focuses on the exposition of the first commandment in the Heidelberg Catechism (HC). Reconstructions of the original German and Latin texts are presented. Zacharias Ursinus, the primary author of the HC, was a student of Philipp Melanchthon in Wittenberg. Two important publications of Melanchthon have been revisited in search of the theological background and context behind the HC. Ursinus' expositions of the first commandment in his Small and Large Catechisms, as well as some of the insights into his dogmatic lectures are explained in an effort to create a better understanding of the exposition of the HC.

Die eerste gebod in die Heidelbergse Kategismus: Teologiese insigte van Phillipp Melanchthon en Zacharias Ursinus. Die artikel fokus op die uitleg van die eerste gebod in die Heidelbergse Kategismus (HK). Rekonstruksies van die oorspronklike Duitse en Latynse tekste word voorgelê. Zacharias Ursinus, die primêre outeur van die HK, was 'n leerling van Philipp Melanchthon in Wittenberg. Twee belangrike publikasies van Melanchthon is nagevors in die soeke na die teologiese denkwêreld as agtergrond tot die HK. Ursinus se uitleg van die eerste gebod in sy Klein en Groot Kategismusse, asook sommige van die insigte wat in sy die dogmatieklesings vervat is, word verduidelik in ' $n$ poging om ' $n$ beter begrip van die uitleg van die HK teweeg te bring.

\section{Introduction}

My contribution to the celebration of the 450-year existence of the Heidelberg Catechism (HC) focuses on the first commandment. In the first section of the article, a reconstruction of the original German and Latin texts will be presented for the sake of making it available to readers who might not have access to these sources.

Thereafter, the expositions of the first commandment by Philipp Melanchthon (1497-1560) and Zacharias Ursinus (1534-1583) will receive attention, since present-day researchers agree that Ursinus was the primary author of the $\mathrm{HC}^{1}$ (cf. Sturm 2000; Bierma 2005; Ehmann 2010; Van Wyk 2011; Walker 2010; Theißen 2012; Bierma \& Gunnoe 2013). Ursinus initially studied in Wittenberg, where Philipp Melanchthon had a huge influence on his formation personally and as a theologian. Although Ursinus had not repeated all the thoughts and ideas of his mentor in his exposition, he did follow him on the important matters. It is therefore important to acquaint the readership (especially those outside the German-Lutheran tradition) with the insights of this important Wittenberg reformer. Personally, Ursinus made valuable contributions to the understanding of the first commandment prior to, during and after the meetings of the task team that assisted him in the writing process. The development of his insights into this commandment makes for interesting reading.

\footnotetext{
1.Not a single original source on the authorship of the $\mathrm{HC}$ has been preserved. The title page and the preface by Elector Frederick ili make no mention of the author and therefore the question will always remain open (Metz 1985:583; Bierma \& Gunnoe 2013:73). There are three theories on the authorship of the HC. (1) It is widely accepted in academic circles today that Zacharias Ursinus was the primary author of the HC. By observing the many similarities between the $\mathrm{HC}$ and his two catechisms, one can hardly reject this thesis (Sturm 2000). Although his important role cannot be doubted, there is general agreement that he was not solely responsible for writing the HC. (2) During the 18th and 19th centuries, the theory of Heinrich Alting (1583-1644) was promoted, namely that Ursinus and Caspar Olevianus had been jointly responsible for writing the HC. Present-day scholarship rejects this theory (Sturm 2000). However, in one levianus had been joinly responsible for wring the HC. Present-day (2cholarsip of the most recent articles on the HC, Blerma and Gunnoe (2013.76-77) plead for this theory not to be rejected completely, because Olevianus had played a much bigger role than recent scholarship gives him credit for. For instance, similarities between the HC and his Vester Grundt (1567) are too obvious to be ignored. Although this exposition of the Creed could not have been used as a draft by the task team, the role played by him must have been bigger than anticipated. (3) It is generally accepted that an 'imperial theological commission " was ultimately responsible for the HC. Ursinus, as a member of this task team, had most probably been responsible for the writing of most of the text. One could therefore argue that the HC was a team effort and that Ursinus was the dominant member of this team. The argument is based on the words in the preface to the Church Order of 1563, which stated that the HC was a team effort. This task team comprised the lecturers of the Faculty of Theology (Ursinus, Emmanuel Tremellius, Pierre Boquin and Wenzel Zuleger), the superintendents (Olevianus, Johannes Veluanus, Johannes Willing, Johan Sylvan and Johannes Eisenmenger), church officials and other men of faith (Adam Neuser, Petrus Macheropeus, Tilemann Murnius, Johannes Brunner, Michael Diller and Konrad Marius), as well as two eminent personalities (Stephan Cirler and Thomas Erastus, Professor of Medicine). The deacon, Wilhelm Klebitz, was probably also included (cf. Noltensmeier 2012:25; Mühling 2012:52-55; Bierma \& Gunnoe 2013:74).
} 
Within the limits of the space available, using mainly footnotes, the expositions of Melanchthon and Ursinus will be brought into discussion with contextual questions and problems, especially those faced by South Africans who have to live in a complex, pluralistic society.

\section{The text}

\section{Sunday 34: Question and Answer 94 and 95}

\section{The original German version}

Ich bin der HERR dein Gott /

Der ich dich auß Egyptenland /

au $\beta$ dem Diensthaus gefüret habe.

Du solst kein ander Götter für mir haben.

Was erfordert der Herr im ersten Gebot?

Dasz ich bey verlierung meiner seelen heil und seligkeyt

alle abgotterey, zauberey, aberglaubische segen,

anrufung der Heiligen oder anderer Creaturen,

meiden und fliehen sol,

und den einigen waren Gott recht erkennen,

im allein vertrauen,

In aller demut und gedult,

von im allein alles guts gewarten,

un in von ganzem herzen lieben, fürchten un ehren

also dasz ich ehe alle creaturen ubergebe,

den in dem geringsten wider seinen willen thue.

Was ist Abgötterey?

An stat des einigen waren Gottes,

der sich in seinem wort hat offenbaret,

oder neben demselbigen etwas anderst dichte oder haben,

darauff der mensch sein vertrauen setzt.

\section{The Latin version of 1563}

Ego sum Dominus, Deus tuus,

Qui eduxi te ex Aegypto, domo servitutis.

Non habebis deos alios in conspectu meo.

Quid postulat Deus in primo praecepto?

Ut, quam mihi chara est salus animae meae, tam studiose vite et fugiam omnem idololatriam, magiam, incatationem, superstitionem, invocationem sanctorum, aet caeterarum creaturarum; unicum autem et verum Deum recte agnoscá, ipsi soli fidá, summa humilitate \& patientia me illi subjiciá, ab eo solo omnia bona expectem, denique intimo cordis affectu ipsum amem reverear, venerer; adeó ut omnibus potius creaturis renunciem, quan ut vel minimu contra eius voluntatem committá.

\section{Quid est idololatria?}

Est loco unius Dei, aut praeter unum illum \& verum Deum, qui se in verbo suo patefecit, aliud quippiam fingere aut habere, in quo spem reponas.

2.The original text of the Heidelberg Catechism, printed three times in Heidelberg in 1563 , is lost. It is therefore impossible to reconstruct an exact version of the original. However, there are texts claiming to be copies of the original. Three German texts have come into the public domain via modern electronic technology. (1) A text in the library of the University of Heidelberg, by Christian Bähr, dating back to 1795. A photocopy of this text is available in Heimbucher, Schneider-Harpprecht and Siller (2012). (2) A copy of a text that was used by Albrecht Wolters in Bonn, dating back to 1864 (cf Wolters [1846] 2012). (3) The Albrecht Wolters in Bonn, dating back to 1864 (cf. Wolters [1846] 2012). (3) The copy of the tercentenary edition of the German, Latin and English texts published in 1863 in New York (cf. German Reformed Church in the United States of America (GRCUS) 2012). Reconstruction of the original Latin texts can be found in GRCUS (1863) and Heimbucher et al. (2012). The text in Heimbucher is based on a text that can be found in the Johannes a Lasco University in Emden, and is believed to be the oldest text available (cf. Ulrichs 2012:67).

\section{The expositions of Philipp Melanchthon}

As stated earlier, Zacharias Ursinus is believed to be the primary author of the HC. It is important to remember that he studied for seven years in Wittenberg where Philipp Melanchthon became his academic and personal mentor. Melanchthon's (indirect) influence on Ursinus went back to his catechesis lessons as a schoolboy in Breslau. The local minister, Ambrosius Moiban, was a friend and theological compatriot of Melanchthon, who had written a short catechism in Latin (1533), as well as a comprehensive one in German (1535). Already as a catechumen, Ursinus had therefore been exposed to the influence of Melanchthon. He started his studies in Wittenberg in 1550 as a 15 -year-old boy. Melanchthon was so impressed by his academic brilliance that he took him with to the religious disputation in Worms in 1557. On central theological questions, such as the doctrines of predestination, the free will and Holy Communion, Ursinus had remained loyal to his teacher until his death. Melanchthon was also the one who had encouraged him and made it possible for him to study in Switzerland after completing his studies in Wittenberg (cf. Ehmann 2010, 2012; Van Wyk 2011:83-90).

Some scholars are of the opinion that the $\mathrm{HC}$ is a synthesis of Melanchthon's and Calvin's theologies - and should therefore be named the 'third theology' (Sturm 2000:1515). This theory is not totally correct, as many other theological influences can be identified in the $\mathrm{HC}^{3}$ However, there can be little doubt about the fact that Melanchthon had an influence on the other authors of the HC. His influence was not limited to Ursinus, since he had a huge influence in the Palatinate (cf. Strohm 2013; Gunnoe 2013). It is also possible that he influenced other members of the Faculty of Theology in Heidelberg, who worked with Ursinus on the task team that wrote the Catechism. ${ }^{4}$ Even though Ursinus (and the task team) did not use specific formulations of Melanchthon, he shaped their understanding of the commandments. Studying Melanchthon's exposition of the first commandment gives one a good idea of the climate of interpretation in which Ursinus developed as a student and young academic.

We will be concentrating on two publications of Melanchthon in which he made valuable methodological, exegetical and hermeneutical remarks on the first commandment. The first publication, the 1521 edition of his Loci Communes, is well-

The widely used dictum states that the $\mathrm{HC}$ is known for its 'Lutherische Innigkeit, melanchthonische Klarheit, zwinglische Einfachheit und calvinisches Feur' (cf. Noltensmeier 2012:24). In his inaugural speech as professor in Dogmatics in Heidelberg, Ursinus made the statement that theological training at a university was a dubious undertaking. This could only be justified if the honour of God (Calvin), the salvation of the people (Luther) and the comfort of the conscience (Melanchthon) were to receive due attention (cf. Ehmann 2010:96, 2012:38-39).

4.During the reign of Otto-Heinrich (1556-1559), the Palatinate became a Protestant area. On 16 April 1556, the Confessio Augustana (written by Melanchthon; cf. Jung 2010:44-48) was adopted as the official confessional document. Self-evidently, other works of Melanchthon would also have been held in high esteem. After his visit to Heidelanch his visit to Heidelberg in 1557, the lecturers of the Faculty of Theology had been bound not only by the $C A$, but also by the Apology of Melanchthon (Strohm 2013:52). Tilemann Heshusen, dean of the Faculty of Theology during the Eucharist controversy (1559-1560), was a pupil of Melanchthon, but rejected the Zwinglian perspective. Melanchthon was consulted and his advice on formulating a middleposition was accepted by Frederick III. In this way, Melanchthon had determined the unique course of the Palatinate (cf. Gunnoe 2013:61-63). 
known in reformed circles. The second publication, the 1553 German version of the Loci known as Heubtartikel Christlicher Lere, is most probably not well-known in reformed circles outside Germany, since it has only recently (2010) become available to the public in general. In this publication, one will find a far more comprehensive exposition of the first commandment than in the older, Latin versions of the Loci.

\section{Philipp Melanchthon's 1521 edition of the Loci Communes}

Philipp Melanchthon was born in 1497 in Bretten, a small town near Heidelberg. He studied in Heidelberg from 1509 to 1512. After completing a Master's degree in Greek in Tübingen, he was appointed in 1518 as professor in Greek in Wittenberg. He became one of the most influential reformers of the 16th century, and was known as the 'praeceptor Germaniae' [teacher of the German nation] (Jung 2010:7; Selderhuis 2010:9-28). Melanchthon was called to Heidelberg twice, but preferred to remain in Wittenberg. He did, however, visit Heidelberg in 1557, where he influenced the transformation process in the Palatinate (cf. Strohm 2013:51). His influence impacted the theological thinking of large sections of the reformation, as well as those who were responsible for drafting the HC.

As early as 1521, the young Philipp published the first edition of his Loci Communes 5 [Fundamental Notions of Theology, or Grondbegrippe van die Teologie]. In this publication, he provided expositions of the central concepts and notions encountered in the Bible, such as God, sin, love and righteousness. He also gave attention to the notion law and, within this framework, an exposition of the first commandment.

Melanchthon's LC also addressed the laws of the Bible, including the first commandment, under the heading 'de divinis legibus' [on the divine laws]. During the first years of the reformation, the emphasis fell on the problem of the law per se. As Luther's coworker, he was required to explain why it was necessary to distinguish between law and gospel as the 'highest art of theology' (cf. Lohse 1995:284-287). Due to the misunderstandings concerning Luther's theology, he had to assist in explaining why the moral law (of the Old Testament) had retained its authority over Christians and what the prerequisites for obedience to the Ten Commandments were.

The first important matter addressed by Melanchthon was the necessity to differentiate between moral, legal and ceremonial laws. Not all legal and ceremonial laws of the Old Testament retained validity for the church. In contrast, the moral laws have. The Ten Commandments fall under the moral laws and form the basis of biblical morality.

The second important principal of explanation discussed by Melanchthon concerns the 'Christological elucidation of the Moral Law'. Hereby is meant that Christ's understanding of the law ought to be explained and that our understanding of the law should not bypass Christ. According to Melanchthon,

\footnotetext{
5.Loci communes originally meant 'general (finding) places' (Gemeinplätze), Melanchthon used these words, indicating a textbook for Dogmatics. The title Loci communes rerum theologicarum could therefore be translated as 'The main aspects communes rerum theologicarum could therefore be translated as 'The main aspects of theology' (cf. Pöh
}

there cannot be any doubt that Christ wanted the first three commandments (and not the first four commandments as stated in HC Q \& A 93) to be explained from the perspective of love for God (Mk 12:30; Dt 6:5). The first commandment expects faith, the second glorification of his name, and the third tolerance or endurance (tolerantiam/Erduldung) of his work in us (Melanchthon [1521] 1997:115 = LC 3,59). To trust, praise and tolerate God is summarised in the words: 'We should love the Lord with all our heart' (Melanchthon [1521] 1997:117 = LC 3,62). Only those who love God would be willing to honour him by obeying his commandments (Melanchthon ibid:113 = LC 3,49-50).

The third aspect of Melanchthon's early contribution to the exposition of the first commandment has to do with our human ability to obey it. The free will of man cannot ensure trust, praise and tolerance (Melanchthon [1521] 1997:115-117 = LC 3,60-61). According to him, we can only obey this commandment when we are moved to do so by the Holy Spirit. Natural man is not able to do so on his own (Melanchthon ibid:117 = LC 3,64-66). To explain this statement, Melanchthon used the argument of the affects.

The first commandment, according to him (Melanchthon 1997), has to do with the spiritual affect (affectus) ${ }^{6}$ which:

non habebis deos alienos, proprie ad affectus referatur, ne quid amemus, ne quid formidemus praetor deum, ne nostris opibus, virtute, prudential, iustitia aut ulla plane creatura fidamus, sed sola dei bonitate. [enables us to love and fear nothing besides God, preventing us from putting our trust into our possessions, virtues, cleverness, righteousness or trusting one or the other creature, but to trust God's goodness alone.] (p. $113=$ LC 3,50)

This exposition falls back on Martin Luther's explanation of the first commandment in his Sermon von den guten Werken of 1520 where he stated: 'Weil ich allein Gott bin, sollst du auf mich alleine deine ganze Zuversicht, Trauen und Glauben setzen und auf niemanden anders' (WA 6,209,26-27). In fact, already in 1518, Luther wrote these famous words in his Instructio pro confessione peccatorum:

Einen Gott haben heißt, einen solchen haben, von dem du zuversichtlich erhoffst, daß du Hilfe erfährst in allem Bösen ... / 'Deum habere est talem aliquem habere, a quo confidas te adiuvari in omnibus malis ... (WA 1,258,4-5)

Melanchthon, in the footsteps of Luther $^{7}$ who in the footsteps of Jesus, desired to state that obedience to the first

6.An affect (Affekt, affek, affectus) is a human emotion, passion or vehement. Melanchthon distinguishes betus) is a hom Melanch and (2) the spirtual (spirituales affectus). The (1) thatural affect is propelles affectus) and (2) the spiritual (spirituales affectus). The natural affect is propelled by human will, whilst the spiritual affects are given/[gifts from the Holy Spirit by the Holy Spirit. The natural affects are self-love and disparaging of God. The spiritual affects, on the other hand, are disparaging of oneself and holding God in high esteem. Melanchthon argues that man could only love God when he is overpowered by the love of God. The 'stronger power of God' has to liberate us from our earthly bondages and desires, as well as our egocentricity (cf. Melanchthon [1521] 1997:44-45, fn. $83=$ LC 1,65)

7.Luther explains the first commandment in his Small Catechism in the following way: 'We should fear, love, and trust in God above all things' (Concordia 2005:343). In the Large Catechism he says: 'What does it mean to have a god? Or, what is God? Answer: A god means that from which we are to expect all good and in which we Answer: A god means that from which we are to expect all good and in which we are to take refuge in all distress. So, to have a God is nothing other than trusting and believing Him with the heart. I have often said that the confidence and faith of the heart alone make both God and an idol. If your faith and trust is right, then you god is also true. On the other hand, if your trust is false and wrong, then you do no have the true God. For these two belong together, faith and God ... Now, I say that whatever you set your heart on and put your trust in is truly your god' (Concordia 2005:385). Ebeling (1969) and Bayer (1995) can be consulted concerning Luther's understanding of this commandment. 
commandment centres in the love for God. This love must be given to us by the Holy Spirit. We are not capable of this love by ourselves and should not even try to do so, as Christ (Jn 4:23) has taught us that 'the true worshippers will worship the Father in spirit and truth, for they are the kind of worshippers the Father seeks'. Melanchthon accordingly appealed that we should be open to the Holy Spirit as this affect will guide us in religious practices that would please God (Melanchthon [1521] 1997:115 = LC 3,56).

Melanchthon summarised his exposition by underlining that obedience to the first commandment is nothing more than loving the one, true God (Dt 6:5; Mk 12:30). To love God means to wholeheartedly embrace God's will - the will that also dooms and kills (Melanchthon [1521] 1997:119 = LC $3,69)$.

\section{Philipp Melanchthon's 1553 edition of the Heubtartikel Christlicher Lere}

A few introductory remarks need to be made about this publication:

- This was the first German version of the Loci and was revised by Melanchthon for a last time in 1558.

- The book was originally written in German and not in Latin.

- This edition of his Loci is a far more comprehensive work than the first Latin edition of 1521. In this edition, the first commandment received more attention than in the earlier editions.

\section{Points of departure}

Before Melanchthon arrives at a detailed explanation of the first commandment, he lays down a few theological points of departure. He starts with the pronouncement, which many people of the 21 st century ${ }^{8}$ may find overstated, namely that all people know about a creator, but not all know who the one, true God is. According to him, this God is none other than the God who had led Israel out of Egypt. This God, the creator of everything and the liberator from captivity, is the one who will not allow his people to worship another god. Not enough is said with this, however, as we look at the relevant commandment as Christians. He therefore adds the interesting remark that the exodus from Egypt was a miracle worked by God and that it was the forerunner to the greatest miracle that was to come, namely the resurrection of Christ. The God, who must therefore be respected and trusted, is the Lord who had been responsible for the miracle of the exodus $^{9}$ and had given the promise of the Messiah to Israel and the other nations. In other words, the God of the first commandment is, according to Melanchthon, the God of the exodus who redeemed us from death through the cross and

8.The African theologian, John Mbiti (1985:29), has been bold enough to state that all Africans know (and believe in) God, the creator. Present-day European (Van den
Brink \& Van der Kooi 2012:48-52) and North American theologians (Plantinga, Thompson \& Lundberg 2010:77-99), to the contrary, are confronted with the fact that most of their countrymen no longer know God as creator.

9.According to Melanchthon, all the miracles of the Old Testament (the exodus included) urge people to look at Christ. He is therefore of the opinion that the exordium of the Ten Commandments should be interpreted Christologically (Melanchthon [1553] 2010:180 = HL 204-205,15-16). the resurrection of Jesus Christ. This God is totally different to the idols and therefore in no way to be compared with the 'creator' of the world religions (Melanchthon [1553] 2010:179-180 = HL 203-204,20-34).

The second introductory remark has to do with the affects. Here, the author links this notion to sin. Sin means that man does not want to love and respect God as he expects of us (Dt 6:5). This has to do with the inclination and propensity of the flesh. Christ, however, works through his gospel and Holy Spirit, and in this way enables sinful man to obey the commandment, which in the deepest sense, is nothing else than loving God (Melanchthon [1553] 2010:180-181 = HL 204,30-206,3-4).

The third theological perspective to keep in mind has to do with the relationship between law and gospel. Melanchthon reminds us that, in line with the second use of the law, ${ }^{10}$ hearing it creates fear of God's wrath and judgement. However, by hearing the good news of the gospel, and through the work of the Holy Spirit, we learn about the forgiveness of sins. In this way, we are drawn from the fear of his wrath into the experience of his mercy. Through this process, the Holy Spirit works faith, comfort and joy - and that is the starting point of obedience to this commandment (Melanchthon [1553] 2010:181 = HL 205-206,15-29).

The following words of Melanchthon (2010) could be regarded as a summary of his understanding of the first commandment thus far:

Dieses erst und hohist gebott ist das nottigest. Denn engel und menschen sind furnemlich geschaffen zu erkantnus des wahrhafftigen gottes und das wir yhm gleichformig sein solten, yhn recht erkennen, anruffen, preisen und lieben und wissen, das ehr wahrhafftig un $\beta$ leben, weißheit, gerechtikeit, narung und alle guter gibet, und yhm darumb dankbar und gehorsam sein etc. Dweil nu die menschen grausamlich von diesem wahrhafftigen gott abweichen, sind erstlich alle menschen verdampt. Dises sollen wir betrachten, das wir gottes gerechten zorn erkennen, vor yhm erschreken und gnade suchen durch glauben und vertauen uff den mittler Ihesum Christum. (p. 183 $=$ HL 208,20-24)

\section{The good works that come forth from the first commandment}

Melanchthon had defined six 'good works' that could be associated with this commandment (cf. Melanchthon [1553] 2010:181-183 = HL 205,30-208,15):

1. This commandment creates correct knowledge of the true God - the God who revealed himself in the exodus and in Christ and who trains the obedient person to accept this correct knowledge of God by faith. Whoever accepts this God in faith, will distance himself from all idolatry and teachings that are in conflict with the biblical message.

10.Classical reformation theology operates through two or three uses or functions of the law. The first use (primus usus) has to do with the effort to enhance the wellthe law. The first use (primus usus) has to do with the effort to enhance the wellbeing of society. The second use (usus elenchticus) has to do with the discovery of sin by listening to God's law. The law is used in a third way (tertius usus legis) when is used as a guideline for Christian living. In an un-Lutheran way, Melanchtho promoted the third use of the law. At least indirectly, he had a big influence on the composition of the third part of the HC, namely the life of gratitude (cf. Busch 2013; Den Hertog 2012, 2013; Theißen 2012). 
2. Obedience to the first commandment leads to the fear of God's wrath, and simultaneously creates fear of the true, living God. However, through hearing the gospel we discover his love and mercy.

3. Obedience to this commandment creates true faith, trust and comfort in Christ, and this is the prerequisite for knowledge of the true God - the God of Abraham who made and kept his promises concerning the Messiah and the forgiveness of sin.

4. The fruit of this commandment is love for and joy in God. Obedience to this commandment fills us with joy and comfort in God's mercy, and this joy and comfort make it possible to love God.

5. This commandment creates hope for believers. Trust in the one, true God comforts us with the promise of eternal salvation and assistance in difficult times. The fruit of hope is patience and joyfulness. The patience that Melanchthon speaks about does only have to do with the irritations of life, but also with obedience to the will of God in times of suffering.

6. The last fruit of the first commandment has to do with humility, meekness and submissiveness. Through knowing our own weaknesses, we can discover the care and protection of the Lord.

\section{Sin against the first commandment}

Melanchthon ([1553] 2010:184-186 = HL 208,1-211,27) contrasted sin against the first commandment in an order of nine grades - from the worst conceivable transgression to sins that are not regarded as 'deadly sins'.

The most serious transgression (worst grade) of the first commandment is to declare that God does not exist or that he is an unfair judge, that he does not regard people and that he does not bring anything to pass. According to Melanchthon, this is typical of Epicurus, Plato and the Stoics.

The second grade concerns putting your trust into another god, giving human beings the glory that God alone deserves and invoking the dead such as the saints.

The third grade concerns sorcery and witchcraft (Zeuberey). The worst form of witchcraft is magic (magica), since this form of evil has to do with a partnership with the devil. ${ }^{11} \mathrm{He}$ defined sorcery as an act whereby evil-minded people rely on the enemies of God to help them harm other people. He also defines this as fortune-telling, soothsaying and superstition such as trusting certain individuals to heal all kinds of diseases through magic (Melanchthon [1553] 2010:184-185 = HL 208,20-25). ${ }^{12}$

The fourth grade concerns accepting Jewish, Muslim and heretic images of God and not embracing the image of God revealed by Jesus Christ. The first commandment, according

11.In this regard, Melanchthon was still bound to the late-Medieval understanding of witchcraft (cf. Van Wyk 2004:1205-1209).

12.Interestingly enough, Melanchthon's understanding of witchcraft, sorcery and magic correspond to the African understanding thereof (cf. Van Wyk 2004:1210-
1224). Hopefully, African theologians will discover Melanchthon as someone $1224)$. Hopefully, African theologians will
relevant to their questions and problems. to Melanchthon, is transgressed through accepting the theory of Mani that postulates two divine principles, namely a good and an evil one. Mani propagated the idea that both a good and an evil 'god' exist that competes to control life. This conviction is not reconcilable with the biblical teaching that God is the all-encompassing reality. According to him, it would also be a transgression of this commandment if one accepts the teaching of Samosatenus, who believes that Jesus is a mere human being.

The fifth grade concerns living without faith in and love for God, and rejecting the idea of repentance.

The sixth grade concerns falling into despair by noticing only God's wrath and failing to see his forgiveness and the hope that accompanies it. Sin, therefore, is to constantly fall into doubt about God's grace and forgiveness.

The seventh grade concerns putting trust into rituals, spirituality and religious orders, and in this way deprives Christ of his honour.

The eighth grade concerns developing trust in one's own holiness, cleverness and power.

The ninth grade concerns turning one's back impatiently on God in times of suffering.

\section{Melanchthon and the Heidelberg Catechism}

The obvious question that should be answered has to do with the comparison between Melanchthon and the Catechism - what perspectives are shared by the Catechism and Melanchthon, what important perspectives of Melanchthon have been omitted from the Catechism, and what has the Catechism contributed to the 16th century debate that Melanchthon still lacked? The intention is not to downplay the HC because it says less than Melanchthon. Obviously, because of its brevity, the $\mathrm{HC}$ excludes some aspects that Melanchthon includes. The theory is that by reading Melanchthon, one gets an idea of the world of thought of, at least, Ursinus.

Both the $\mathrm{HC}$ and Melanchthon concentrate on knowledge about the true God of the Bible. Melanchthon, however, is more specific by referring to the God of the first commandment as the God of the exodus and the resurrection. The God of the first commandment worked and is still working miracles. $\mathrm{He}$ is therefore not only a postulate of practical reason, but a living and acting spiritual being. He is not one of the two 'spiritual forces' that Mani speaks about, but the 'alldetermining reality'. Knowledge of and obedience to this God develops through experiencing the forgiveness, hope and joy in Jesus Christ.

Both the HC and Melanchthon explain that obedience to this commandment has to do with loving, fearing and honouring God. The value of Melanchthon's explication of the 'fear of God' has to do with his reference to the second function of 
the law. He teaches us that not only does 'fear' concern the 'respect of God', but also the fear of his wrath. Not many present-day theologians are willing to speak about the wrath of God, because they believe that the world only wants to hear about his love (cf. Miggelbrink 2002:9-11). In this way, the biblical message is being distorted. ${ }^{13}$

The HC shares Melanchthon's view that we should expect all good things from this God. Melanchthon added the perspective that bad things also came from God. By rejecting the idea of a 'devil' that competes with God on an equal basis, he could reason, along with the $\mathrm{HC}$, that we should humbly and patiently love and fear God, but add 'also in times of suffering'.

The HC shares Melanchthon's view of the world as a place filled with magic, sorcery, witchcraft and ancestor veneration. Concerning occultism and magic, Melanchthon mentioned 'religious rites' and not 'superstitious rites' as the HC does. This formulation could be explained against the background of the adiaphora debate in which Melanchthon was caught up (cf. Jung 2010:112-113). Melanchthon understood the clinging to traditional rituals associated with ancestor veneration as a transgression of the first commandment, and thus as sin.

Although one cannot expect theological arguments on the possibilities of obedience to this commandment in the text of a catechism, it would be wise to remind students and ministers about Melanchthon's arguments concerning the affects. Despair could easily creep in when believers do not allow for the work of the Holy Spirit and 'tolerate' it that God wants to work in us.

Melanchthon moves considerably closer to modern man with his argument that sin, in the deepest sense of the word, is 'saying that God does not exist'. The HC, on the other hand, sounds much more postmodern by arguing that sin has to do with 'inventing another God'.

The HC has a more pastoral approach by starting the exposition - expressing fear that the disobedient could 'endanger their own salvation' by engaging in magic and other superstitious activities.

\section{The exposition of Zacharias Ursinus}

Quirinus Reuter says (cf. Mühling 2012:56; Gunnoe 2013:65) in the preface of the Opera Theologica (vol. 1, 10) of Zacharias Ursinus (1612) that he received a commission from Frederick III to write two catechisms: 'Unam quidem maiorem, pro studiosis adultioribus, et scholis maioribus, alteram minorem, captui populi et puerilis aetatis magis accommodatam in chartam conjecit...' Since the August Lang edition of 1907 these two catechisms have been known as Maior and Minor. They were revised by the imperial theological commission into a new catechism (published on 19 January 1563 - without question 80), which would later become known as the HC.

13.I have made two contributions in this regard (cf. Van wyk 1996, 2006).
This 'new catechism' (publica Catechesis) combined the two wishes of the elector, namely for a catechism that could function as norm for preaching and teaching, and a 'people's catechism' (Volkscatechismus) by which young and old could be educated. ${ }^{14}$ The third official edition (the fourth, according to Metz 1985:583) was taken up in the Church Order of the Palatinate of 15 November 1563, and in this way became the 'most important document of the state' (Mühling 2012:56; Gunnoe 2013:66-67). The Catechesis Minor (1561, or early 1562) was written in Latin and the original manuscript is available in Ursinus' preserved private library. This catechism was used for the instruction of children and new church members. The Catechesis Maior (Summa theologiae), also written in Latin in 1562, was used as a textbook for senior students in Dogmatics at universities (cf. Bierma \& Gunnoe 2013:78-79).

Many formulations of the Minor and Maior were taken up pleraque transcripta in publicam Catechesin (Metz 1985:583; Sturm 2000:1514). Some of Ursinus' original formulations were rejected by the commission. It is therefore a valuable academic exercise to revisit the formulations of the two catechisms ${ }^{15}$ in order to identify important perspectives on the first commandment that were not taken up in the HC.

\section{Small Catechism ${ }^{16}$}

\section{Question and Answer 80}

Q. What are the commandments of the Decalogue?

A. First: Hear, O Israel. I am the Lord your God, who brought you out of the land of Egypt, the house of bondage. You shall have no other gods before me.

\section{Question and Answer 82}

Q. What does the first commandment require?

A. That we detest all idolatry with our whole heart and flee from it with the utmost zeal. (HC 94)

\section{Question and Answer 83}

Q. What is idolatry?

A. It is to invent or have anything other than or in the place of the one, true God, who has revealed himself to us in his Word, on which our hope and trust depend; or anything that we love or fear more than him or honour contrary to his command. (HC 95)

14. A catechism attempts to formulate the relevant, essential and existential aspects of the gospel to contemporaries. The HC succeeded doing this in an outstanding way (Strohm 2012:61).

15.Both these catechisms have many similarities to Calvin's Catechism, the Catechism of Emden and Theodor Beza's Catechism of Geneva. It is also clear that Ursinus had made extensive use of Luther's Catechisms, Calvin's Catechism (French 1541, Latin 1545) and Institutio, and Melanchthon's Examen Ordinandorum (1552) and Loci, and other reformed and Lutheran catechisms, such as Johannes Brenz' Fragestück des Christlichen glaubens für die Jugendt (1535) that had a more Zwinglian approach to Holy Communion (cf. Strohm 2012:63). He might even have looked into the Catechism of Basel (1531) written by Oecolampadius, the Catechism of Zürich (1534) by Leo Jud, as well as Martin Bucer's Straatsburger Catechism of 1534 (cf. Lee 2013:41-46). The fact that Ursinus and the Catechis Commission 1534 (cf. Lee 2013.41-46). The fact that Ursinus and the Catechis Commission Heinrich Bullinger on 14 April 1563 saying 'Non unius, sed multorum sunt collatae piae cogitationes' (Metz 1985:583).

16.The translations presented here are taken from Bierma (2005:156-157). The original American translation has been kept unchanged, in spite of grammatical and stylistic problems. 


\section{Large Catechism ${ }^{17}$}

\section{Question and Answer 155}

Q. What is the first commandment?

A. 'Hear, O Israel: I am the Lord your God, who brought you out of the land of Egypt, out of the house of bondage. You shall have no other gods before me.'

\section{Question and Answer 156}

Q. What does God forbid in this commandment?

A. That we neither neglect nor give to another the worship we owe him.

\section{Question and Answer 157}

Q. What is the worship that he demands we render to him?

A. That we acknowledge him as our God according to his Word, firmly believe every word of his, place all our trust in him alone, look to him for all good things, love and honor him above all, humble ourselves before him, and patiently endure what he inflicts upon us.

\section{Question and Answer 158}

Q. When Moses speaks to people of Israel, does he also address us?

A. No less than he did them. First, because God was not producing then for the first time the law summarized in the Decalogue, but he was repeating and clarifying for the people of Israel not only what he required of them but also that for which all rational creatures had been made. Second, inasmuch as we have been engrafted into Christ, who is the natural seed of Abraham, we are the spiritual children of Abraham and Israel.

\section{Question and Answer 159}

Q. Why does God call himself 'Lord'?

A. To remind us that he has full authority to rule us since he is the creator and sustainer of all things.

\section{Question and Answer 160}

Q. Why does he call himself our God, who brought Israel out of Egypt?

A. First, so that we might remember that this God alone is the true God, who revealed himself from the beginning in the church by his sure Word and clear divine testimonies. Second, so that when we consider that we have been saved and delivered from all evil by him, we might realize that we owe him gratitude and obedience.

\section{Question and Answer 161}

Q. What is an 'other god'?

A. Anything besides the God revealed in the church in which people place any trust, or which they love or fear more than or equal to God, or to which they show an honor and reverence for the purpose of worshipping God that is outside of or contrary to the Word of God.

17.The translations presented here are taken from Bierma (2005:191-193).

\section{Question and Answer 162}

Q. Why is 'before me' added?

A. So that we flee all idolatry, not only in the sight of others but also in our hearts, since all things are exposed in the eyes of God.

\section{Corpus doctrinae christianae}

Ursinus had the responsibility of defending the HC theologically. He immediately started using it as his academic textbook. His annual lectures in Dogmatics comprised nothing other than expanded commentaries on the HC. These lectures were collected and published in Geneva in 1584 as Doctrinae christianae compendium. In 1587, a second edition was published in Cambridge as Explicationes catecheticae. In 1591, his successor at the Collegium Sapientiae, David Pareus, revised the volume and published it in Neustadt as Explicationum catecheticarum [...] absolutum opus totiusque theologiae purioris quasi novum corpus. In 1612, Reuter added the publication to the Opera theologica under the title, Corpus doctrinae christianae ecclesiarum a Papatu reformatorum continens explications catecheticas. Many revised editions followed. It eventually became known to South Africans in the Dutch translation as Het schatboek der verklaringen over de Heidelbergse Catechismus (Ursinus [1657] 1978; cf. De Wildt 2013:86-87; the Latin text was not available to the author).

In this publication, Ursinus made remarks on every phrase of the $\mathrm{HC}^{\prime}$ s exposition of the first commandment. I regard the comments that follow as noteworthy.

The one, true God, our Lord is the author and sustainer of all good things. Because Christians know the 'good things' better than the Jews, the Lord expects the church to obey this commandment better than those outside Christ (Ursinus [1657] 1978:253).

The phrase stating that the Lord brought Israel out of Egypt has not got meaning for the Jews only. This phrase is also directed to the church. One should understand this phrase as a metaphor, as an example of all other good things given to us by the Lord on a daily basis. This phrase should remind Christians of God who is not only the God of the old covenant, but also the God of the new covenant (Ursinus [1657] 1978:254).

To know the only true God, one should start by accepting his existence. Doubt about his existence implies disobedience to the commandment. The next step is to show willingness to learn about him. Part of this learning process is to learn about the heresies that exist about the triune God. Self-evidently, this means that one should also learn the doctrine dealing with the trinity (Ursinus [1657] 1978:255).

In these lectures, he reiterated his viewpoint that magic has to do with the signing of a pact with the devil. He, however, also presented us with a new perspective on magic. Magicians, according to him, are people who want 'to do and to know things that are not necessary'. Prophets and fortune-tellers 
are good examples of that. Magicians are also people who use words and rituals to manipulate the forces of life to harm others. Ursinus also associated magic with superstition, which has to do with the association of bad events with certain sounds and interpretations of dreams that could be totally misleading (Ursinus [1657] 1978:256-257).

The commandment expects faith in the God of the Bible. Disbelief would therefore be despising God, unbelief, doubting his love and goodness, and falling from faith after a certain period of time. Faith is always associated with hope. Transgressing this commandment would be falling into despair and hopelessness (Ursinus [1657] 1978:257-260).

By loving God one obeys this commandment. Disobedience would be rejecting his love, but also misleading people about your love for God (Ursinus [1657] 1978:260).

Ursinus associates obedience to this commandment with the 'fear of God'. This 'fear' should be like the fear of a child. It is expecting good things from God all the time - also during bad times (Ursinus [1657] 1978:261-265).

He ended his exposition with a remark that is amazingly relevant to the African situation. Concerning idolatry, he remarked that confessing the true God, but relying on something or someone else, such as ancestors, ${ }^{18}$ constitutes a transgression of this commandment. To imagine God as 'helper', but to rely on the deceased on a daily basis is not what the commandment expects of us (Ursinus [1657] 1978:265-267).

\section{Why all this at this point in time?}

Why this commandment of Melanchthon and Ursinus at this point in time? As South Africans we live in an extremely complicated country. Different cultures, traditions, beliefs, influences, ideologies and levels of education and development come together at this place. Sometimes we feel part of the postmodern world and sometimes we discover that we are still captured in the premodern world. All this contributes to a sense of uncertainty, disorientation and fear - that often spills over into anger, aggression and violence. Should the church want to play any meaningful role in this country, we would need to deal with the most basic and fundamental questions about God, morality and human existence. The first commandment is the foundation of all theology (Barth 1986). We consistently need to return to this point. Melanchthon and Ursinus dealt with this commandment as if they were our compatriots. They also were men of their own time - a time, however, that has many similarities to the world made up of many congregants of the African churches. These two theologians of the 16th century can offer a lot to people who are confronted by similar questions and challenges as they were. The history of theology is important not only to Europe and the United States, but also to Africa!
My final remark has to do with a balanced approach to spirituality. Obviously Melanchthon and Ursinus had an intellectual and rational approach to the Christian faith. As children of the Reformation, we gladly follow in their footsteps. Hopefully, the younger, predominantly African congregations and churches would help the predominantly European section of the church to rediscover the joy and importance of singing - also of the $\mathrm{HC}$ - during church services. The HC was sung, for instance, in Basel (Switzerland) for many centuries since 1743. Unique of the 'Christliche Gesangbuch' was that they had a separate hymn for every commandment (Wennemuth 2012:81). The fact that the $\mathrm{HC}$ was an addendum to many hymnals shows that the reformed tradition was never intended to be an emotionless, rational affair.

\section{Acknowledgements Competing interests}

The author declares that he has no financial or personal relationship(s) that may have inappropriately influenced him in writing this article.

\section{References}

Barth, K., 1986, 'Das erste Gebot als theologisches Axiom', in Theologische Fragen und Antworten: Gesammelte Vorträge: 3 Band (1927-1942), 2nd edn., pp. 127-143, Theologischer Verlag, Zürich.

Bayer, O., 1995, "'Ich bin der Herr, dein Gott...": Das erste Gebot in seiner Bedeutung für die Grundlegung der Ethik', in Freiheit als Antwort: Zur theologischen Ethik, pp. 83-93, Mohr, Tübingen.

Bediako, K., [1995] 1997, 'Christian religion and the African world-view: Will ancestors survive?', in Christianity in Africa: The Renewal of a Non-Western Religion, pp. 210-233, Orbis Books, New York.

Bierma, L. (ed.), 2005, An introduction to the Heidelberg Catechism: Sources, history and theology, Baker, Grand Rapids.

Bierma, L. \& Gunnoe, C., 2013, 'Auteurschap van de Heidelbergse Catechismus', in A. Huijgen, J. Fesko \& A. Siller (eds.), Handboek Heidelbergse Catechismus, pp. 73-83, Kok, Utrecht.

Busch, E., 2013, 'De wet van God volgens de Heidelbergse Catechismus', in A. Huijgen, J. Fesko \& A. Siller (eds.), Handboek Heidelbergse Catechismus, pp. 259-267, Kok, Utrecht.

Concordia, 2005, The Lutheran confessions: A reader's edition of the Book of Concord, based on the translation by W. Herrmann, T. Dau \& G. Bente, revised, updated and annotated by P. McCain, pp. 343, 385, Concordia Publishing House, St Louis.

De Wildt, K., 2013, '1567-1620: Commentaren op de Heidelbergse Catechismus', in A. Huijgen, J. Fesko \& A. Siller (eds.), Handboek Heidelbergse Catechismus, pp. 85-95, Kok, Utrecht.

Den Hertog, G., 2012, “"Ein geringer Anfang ... mit fester Absicht": Die Zehn Gebote als Regeln', in M. Heimbucher, C. Schneider-Harpprecht \& A. Siller (eds.), Zugänge zum Heidelberger Katechismus: Geschichte, Themen, Unterricht., pp. 106-112, Neukirchener Theologie, Neukirchen-Vluyn.

Den Hertog, G., 2013, 'De Tien Geboden in de Heidelbergse Catechismus', in A. Huijgen, J. Fesko \& A. Siller (eds.), Handboek Heidelbergse Catechismus, pp. 293302, Kok, Utrecht.

Ebeling, G., 1969, "'Was heißt ein Gott haben oder was ist Gott": Bemerkungen zu Luthers Auslegung des ersten Gebots im Großen Katechismus', in Wort und Glaube, Band 2, Beiträge zur Fundamentaltheologie und zur Lehre von Gott, pp Glaube, Band 2, Beiträge zur
287-304, Mohr, Tübingen.

Ehmann, J., 2010, 'Zacharias Ursinus und der Heidelberger Katechismus: Ein Lebensbild', Luther 81(2), 90-103.

Ehmann, J., 2012, 'Von Breslau in die Pfalz - die Wege des Zacharias Ursinus', in M. Heimbucher, C. Schneider-Harpprecht \& A. Siller (eds.), Zugänge zum Heidelberger Katechismus: Geschichte, Themen, Unterricht, pp. 33-42, Neukirchener Theologie, Neukirchen-Vluyn.

German Reformed Church in the United States of America (GRCUS), [1863] 2012, Heidelberg Catechism in German, Latin and English with an Historical Introduction, Tercentenary Edition, Charles Scribner, New York. .

Gunnoe, C., 2013, 'De Heidelbergse Catechismus in de Theologische context van de Palts', in A. Huijgen, J. Fesko \& A. Siller (eds.), Handboek Heidelbergse Catechismus, pp. 61-72, Kok, Utrecht.

Heimbucher, M., Schneider-Harpprecht, C. \& Siller, A. 2012, Zugänge zum Heidelberger Katechismus: Geschichte, Themen, Unterricht, Neukirchener Theologie, Neukirchen-Vluyn. (Ein Handbuch für die Praxis mit Unterrichtsentwürfen auf CD-Rom). 
Jung, M., 2010, Philipp Melanchthon und seine Zeit, Vandenhoeck, Göttingen. Kuropka, N., 2010, Melanchthon, Mohr (UTB Profile), Tübingen.

Lee, B., 2013, Catechismi in de gereformeerde traditie: een overzicht', in A. Huijgen J. Fesko \& A. Siller (eds.), Handboek Heidelbergse Catechismus, pp. 37-47, Kok Utrecht.

Lohse, B., 1995, Luthers Theologie in ihrer historischen Entwicklung und in ihrem systematischen Zusammenhang, Vandenhoeck, Göttingen. PMCid:PMC185299

Luther, M., 1883ff., Weimarer Ausgabe, D. Martin Luthers Werke: Kritische Gesamtausgabe, 65 volumes, H Böhlau und Nachfolger, Weimar. [=WA]

Mbiti, J., [1969] 1985, African religions and philosophy, 11th edn., Heinemann, London.

Melanchthon, P., [1521] 1997, Loci Communes, Lateinisch - Deutsch. Übersetzt v H. Pöhlmann, Hrsg von Lutherischen Kirchenamt der VELKD, 2. Aufl., Gütersloher Verlagshaus, Gütersloh. [=LC]

Melanchthon, P., [1553] 2010, Heubtartikel Christlicher Lere, Melanchthons deutsche Fassung seiner Loci Theologici, nach dem Autograph und dem Originaldruck von 1553 herausgegeben von Ralf Jenett und Johannes Schilling, 2. aktualisierte und ergänzte Ausgabe, Evangelische Verlagsanstalt, Leipzig. [=HL]

Metz, W., 1985, 'Heidelberger Katechismus - Kirchengeschichtlich', in Theologische Realenzyklopädie (TRE), vol. XIV, pp. 582-590, De Gruyter, Berlin.

Miggelbrink, R., 2002, Der zornige Gott: Die Bedeutung einer anstößigen biblischen Tradition, WBG, Darmstadt.

Mühling, A., 2012, “'Vornehmstes Stück unseres Regimentes": Die Entstehung des Heidelberger Katechismus', in M. Heimbucher, C. Schneider-Harpprecht \& A. Sille (eds.), Zugänge zum Heidelberger Katechismus: Geschichte, Themen, Unterricht, pp. 51-57, Neukirchener Theologie, Neukirchen-Vluyn.

Noltensmeier, G., 2012, 'Der Heidelberger Katechismus - eine Komposition', in M Heimbucher, C. Schneider-Harpprecht \& A. Siller (eds.), Zugänge zum Heidelberger Katechismus: Geschichte, Themen, Unterrich., pp. 24-29, Neukirchener Theologie, Neukirchen-Vluyn.

Plantinga, R., Thompson, T. \& Lundberg, M., 2010, An introduction to Christian theology, Cambridge University Press, Cambridge.

Selderhuis, H.J., 2010, Praeceptor Europae: Philippus Melanchthon over kerk, recht en universiteit, Theologische Universiteit Apeldoorn. (Apeldoornse Studies \#55).
Strohm, C., 2012, "Was must du wissen...?" Das Anliegen reformatorischer Katechismen', in M. Heimbucher, C. Schneider-Harpprecht \& A. Siller (eds.) Zugänge zum Heidelberger Katechismus: Geschichte, Themen, Unterricht, pp. Zugänge zum Heidelberger Katechismus: Geschichte,
58-64, Neukirchener Theologie, Neukirchen-Vluyn.

Strohm, C., 2013, 'Politiek, kerk en universiteit in de ontstaanstijd van de Heidelbergse Catechismus', in A. Huijgen, J. Fesko \& A. Siller (eds.), Handboek Heidelbergse Catechismus, pp. 49-60, Kok, Utrecht.

Sturm, E., 2000, 'Heidelberger Katechismus', in Religion in Geschichte und Gegenwart $(R G G)$, vol. 3, pp. 1514-1515. Mohr, Tübingen.

Theißen, G., 2012, Glaubenssätze: Ein kritischer Katechismus, Gütersloher Verlagshaus, Gütersloh.

Ulrichs, H-G., 2012, "Akkurat orthodox", doch von "relative Autorität", in M. Heimbucher, C. Schneider-Harpprecht \& A. Siller (eds.), Zugänge zum Heidelberger Katechismus: Geschichte, Themen, Unterricht, pp. 65-76, Neukirchener Theologie, Natechismus: Geschich
Neukirchen-Vluyn.

Ursinus, Z., [1657] 1978, Het schatboek der verklaringen over de Heidelbergse Catechismus, Uit de Latijnse lessen. Deel II, Opgemaakt door David Pareus. Vertaalt door Festus Hommius. Hedendaags Nederlands door J. van den Haar, Van den Tol, Dordrecht.

Van den Brink, G. \& Van der Kooi, C., 2012, Christelijke dogmatiek, Boekencentrum, Zoetermeer.

Van Wyk, I.W.C., 1996, 'Die prediking oor die eindoordeel', HTS 52(2\&3), 501-531.

Van Wyk, I.W.C., 2004, 'African witchcraft in theological perspective', HTS 60(4), 12011228.

Van Wyk, I.W.C., 2006, 'The final judgment in African perspectives', HTS 62(2), 703729.

Van Wyk, N., 2011, 'The Smaller Catechism of Zacharias Ursinus', ThaciSA 3(2), 83109.

Walker, F., 2010, Theological sources of the Heidelberg Catechism, Lexington, KY.

Wennemuth, H., 2012, 'Gesungene Lehre - Katechismus in Liedern', in M. Heimbucher, C. Schneider-Harpprecht \& A. Siller (eds.), Zugänge zum Heidelberger Katechismus: Geschichte, Themen, Unterricht, pp. 77-86, Neukirchener Theologie, NeukirchenVluyn.

Wolters, A., [1846] 2012, Der Heidelberger Katechismus in seiner ursprünglichen Gestalt, herausgegeben nebst der Geschichte seines Textes im Jahre 1563 von Albrecht Wolters, Adolph Marcus, Bonn. 